\title{
Narrativas visuales, experiencias rituales y proyecciones virtuales. Un estudio de caso: la romería de Santa Marta de Ribarteme (Pontevedra)
}

\author{
Visual Narratives, Ritual Experiences and Virtual Projections. \\ A Case Study: The Romeria of Santa Marta de Ribarteme \\ (Pontevedra)
}

\author{
Laura SÁNCHEZ PÉREZ \\ (Centro Asociado a la UNED de A Coruña) \\ 1sanchez@a-coruna.uned.es \\ ORCID: 0000-0003-2455-4115
}

\begin{abstract}
Currently, different forms of ritual participation in romeria converge. Both the promotion of celebrations and the exhibition of experiences through digital media and social networks, transcends the locus of celebration, projecting itself in a virtual space. From this, new formulas of participation arise that also affect the meaning of the religious and community experience. The confluence between the different experiences (religious, tourist and virtual) can generate tensions at the different levels and spaces of participation. The romeria of Santa Marta de Ribarteme (Pontevedra) is one of these cases. This article will explore the tensions and conflicts between the different conceptions of the celebration for devotees, tourists and virtual spectators. The aim is to intuit possible modifications in the communitarian practices and experiences of the ritual.
\end{abstract}

Keywords: Visual Antropology, Romeria, Ritual, Santa Marta de Ribarteme
RESUMEN: En las romerías actuales confluyen diferentes formas de participación ritual. El uso de medios digitales y redes sociales para promocionar la celebración y para exponer las vivencias de los actores sociales trasciende el locus de celebración, proyectándose a un espacio virtual del que surgen nuevas fórmulas de participación, que afectan al significado de la experiencia religiosa y comunitaria. La confluencia entre las diferentes experiencias (religiosa, turística y virtual) puede generar tensiones en los distintos niveles y espacios de participación. Este es el caso de la Romería de Santa Marta de Ribarteme (Pontevedra). En este artículo se exploran las tensiones y conflictos surgidas de las diferentes concepciones del ritual para devotos, turistas y espectadores virtuales, para entrever posibles modificaciones en las prácticas y experiencias comunitarias del ritual.

PALABRAS-CLAVE: antropología visual, romería, ritual, Santa Marta de Ribarteme 


\section{INTRODUCCIÓN}

Este artículo ${ }^{1}$ analiza las diferentes expresiones y experiencias de los participantes en la romería de Santa Marta de Ribarteme (Pontevedra), así como el significado que adquiere el ritual para los distintos actores sociales que participan actualmente de esta celebración de diferentes maneras. Se centra, principalmente, en cómo se construye la proyección de la imagen de la romería a través de los medios virtuales y cuál es su repercusión sobre el significado de la celebración y sobre la participación en el locus ritual. La finalidad es presentar cómo se construyen las experiencias y cómo se difunden, tanto a través de los medios de comunicación como desde los participantes, para entrever posibles modificaciones, tensiones y conflictos derivados de las diferentes concepciones del ritual.

Esta romería ha adquirido una enorme proyección internacional que, además de congregar cada año a miles de personas in situ, también es retransmitida de forma masiva por los medios de comunicación (telediarios, revistas, radio, etc.) y redes sociales. En este escenario se reproducen narrativas visuales que, en sus diferentes interpretaciones, pueden dar lugar a tensiones entre devotos, turistas y espectadores virtuales, generando prácticas que podrían ser interpretadas como agresivas o que modifican el itinerario ritual, lo que, a su vez, podría dar lugar a una reinterpretación de su significado religioso-comunitario hacia el de espectáculo, más ligado al consumo y ocio turístico.

La primera parte de este artículo se dedicará a la aproximación metodológica y a las principales influencias teóricas sobre las que se sustenta el análisis, para introducir el abordaje webnográfico, que se revela como herramienta metodológica complementaria y esencial en la investigación etnográfica actual. En la segunda parte se presentará la romería de Santa Marte de Ribarteme y los diferentes actores sociales, para analizar sus experiencias en el locus ritual; posteriormente, se abordará la proyección en el locus virtual y se analizará la proyección de la romería en los medios de comunicación y en el espacio virtual, para conocer las experiencias registradas por los usuarios virtuales.

\section{APROXIMACIÓN TÉORICA Y METODOLÓGICA}

El análisis parte de los trabajos de observación y documentación gráfica realizados en la romería de Santa Marta de Ribarteme, de 2015 y 2018. Esta investigación personal es parte de un estudio continuado sobre la temática de las romerías gallegas, iniciado en 2005 en la Virgen de O Corpiño (Lalín) y que se ha venido desarrollando de forma intermitente hasta la actualidad en diferentes escenarios de observación de la geografía gallega.

En el caso que nos ocupa, el trabajo de campo realizado se completó con el análisis documental de la difusión de la romería de Ribarteme en los medios digitales. La base documental del entorno virtual que se ha recogido y analizado para este texto está

\footnotetext{
${ }^{1}$ Parte de este trabajo fue expuesto en la comunicación «Incidencias del turismo sobre el Patrimonio Inmaterial. Un estudio de caso: la romería de Santa Marta de Ribarteme (Pontevedra)» presentada en el XVII Congreso Latinoamericano de Religión y Etnicidad «Movilidad religiosa y conflicto. Patrimonio cultural y turismo», que se celebró del 9 al 13 de julio de 2018 en Toro (Zamora). Mi agradecimiento a Pilar Panero y Carmen Morán por invitarme a participar en su panel. También quisiera agradecer a José Luis Alonso Ponga, María Jesús Pena Castro y Vivian P. Rosado Cárdenas las sugerencias aportadas que, sin duda, han mejorado este texto.
} 
conformada por más de 100 medios y noticias de medios nacionales e internacionales ${ }^{2}$, desde el año 2015 al 2019 (principalmente). También se han registrado webs y blogs (turísticos, institucionales y personales) y, sobre todo, los comentarios de los usuarios de redes sociales (Facebook y Twitter) a estas noticias.

La observación de las percepciones recogidas a través de las respuestas y comentarios a noticias concretas sobre la romería de Santa Marta, no deja de ser una aportación más sobre la experiencia ritual que, si bien de forma indirecta, refleja la forma de entender y significar el ritual en un escenario igualmente interrelacionado. No obstante, es preciso aclarar que esta es una visión complementaria y no principal del análisis de las narrativas presentes en la romería de Santa Marta, sobre todo porque el análisis webnográfico y la etnografía virtual se presenta en forma de «captura ${ }^{3} »$ (Beaulieu, 2004; Domínguez Figaredo, 2007): una aproximación a las respuestas espontaneas realizadas por diferentes usuarios que no están sujetas a la aplicación de métodos específicos de recogida de información. Así, siguiendo a Daniel Domínguez Figaredo:

la etnografía virtual podría entenderse como una etnografía estructurada en torno a casos concretos dentro y fuera de la red, vinculados entre sí por medio de complejas relaciones mediadas por artefactos tecnológicos, de los que Internet solo sería uno más de ellos. (2007: 59)

En la actualidad, para los no locales, la fuente de información primaria es Internet: los programas, citas, eventos, se muestran en la red de redes, y la gente consulta noticias, foros, páginas turísticas, etc., en donde obtienen la información sobre la festividad que desea visitar. Al mismo tiempo se socializa a través de las redes sociales, compartiendo noticias, eventos, imágenes, etc., creando conversaciones lentas o intermitentes, exponiendo sentimientos, reconocimiento o aceptación. Internet es, por tanto, un escenario indirecto de participación que también es susceptible de ser analizado.

El interés en el grupo de observadores virtuales radica en conocer cómo interpretan el significado del ritual a través de la exposición de imágenes secundarias (principalmente condicionadas por el subtexto periodístico que reclama su espacio en el entorno virtual) y cuáles son las principales reacciones que suscita; esto es, qué emociones, representaciones e interpretaciones se expresan en los comentarios a dichas imágenes y en qué medida están ligadas al significado ritual; o, desde una aproximación básica, cómo estas narrativas manifiestan elementos más complejos del esquema cultural en un escenario virtual. Como indican Francisco Javier Doménech y Miquel Tirado (2004: 55), apoyándose en los planteamientos de la «teoría del actor-red» de Bruno Latour (2001), «tecnología y sociedad no son esferas separadas, sino algo mutuamente constitutivo y definitorio».

\footnotetext{
${ }^{2}$ En las referencias bibliográficas se indican únicamente las webs y medios digitales que se reseñan en este texto.

${ }^{3}$ Sobre la definición de la etnografía en los espacios virtuales ver Daniel Domínguez Figaredo (2007). Este autor distingue entre las nociones de captura y comparativa, basándose en la definición de Anne Beaulieu (2004) que «introduce el componente de captura para referirse a aquellos extractos conversacionales susceptibles de consideración para la etnografía. Estas capturas pueden ser textos, imágenes, o vídeos» (Domínguez, 2007: 53). No se trata de realizar trabajo de campo en el sentido extenso y convencional, sino de usar Internet como un campo de estudio o, cuanto menos, conociendo las particularidades de las comunidades/actores virtuales analizados. Todo ello teniendo en cuenta siempre que el trabajo de campo, también en Internet, está en constante construcción.
} 
Al poner la mirada sobre este grupo de actores virtuales, también se ponen de manifiesto todas aquellas tensiones que subyacen en la experiencia ritual in situ pero que, amortiguadas por el contexto de la celebración, no sobresalen. De igual modo, el análisis de cómo se construye el discurso visual que se asocia con esta romería servirá de reflexión sobre la intencionalidad de ciertos comportamientos y sobre el objeto moral de los mismos en este tipo de celebraciones. Todo ello, con la finalidad última de explorar las diferentes vivencias de los usuarios en los diferentes espacios, así como las ramificaciones derivadas de esta interrelación.

El abordaje teórico general de este artículo se realiza desde la antropología aplicada, la visual y, sobre todo, la simbólica. Por ello se parte, al menos en el planteamiento inicial, de la idea de performance desarrollada por Víctor Turner (1988). El autor considera que los actos de representatividad (como las fiestas, los carnavales, las romerías, etc.) expresan los principios, valores, realidades y significados de una cultura concreta. La puesta en escena o performance que se lleva a cabo en estas actividades comunitarias tiene como finalidad reproducir un guion preestablecido en el que los individuos reviven su historia particular y su contexto social. A través de la dramatización, ponen en valor su propia cultura, dotándola de un significado constante. Con la performance se valida la experiencia comunitaria, poniendo de relieve los dramas sociales y experimentando sus códigos identitarios. Y esta experiencia se da en dos niveles: en las prácticas, como actores en cuyo papel pueden llegar a conocerse mejor; y, en la observación, se comprenden a sí mismos a partir de la participación, representados por otro grupo de seres humanos.

Esta concepción entronca con la idea de juego profundo desarrollada por Clifford Geertz (1993) a partir de la definición de Jeremy Bentham ${ }^{4}$ (1780), en la que la dramatización de intereses de status no es más que una representación de la matriz social. Sirve para decir algo sobre algo; se vincula una función interpretativa, ya que es una lectura de la experiencia de la cultura local, puesta en práctica a través de una acción concreta. Así, en el caso que nos ocupa, esta romería condensa una serie de símbolos que reproducen un sistema de significados que, al ser mostrados de forma visual, son interpretados por los diferentes interlocutores, manifestando sus tensiones sociales y culturales. Y estas se pueden reproducir tanto en el locus ritual (en mismo tiempo y espacio), como en el virtual (con distintos tiempos-espacios, como explica Hine, 2004).

En la misma línea que expone Salvador Rodríguez Becerra (1989: 147), en este artículo no se van a exponer las diversas funciones de la romería,

pero si conviene recordar que existe un amplio consenso acerca de que la fiesta materializa la identidad social y cultural, los individuos ejercen su condición de miembros de la comunidad, comarca, región o nación, y se reafirman en ella, a la vez que se transmiten mensajes culturales vehiculados por signos y símbolos que sólo los miembros de esa cultura conocen. (Velasco, 1982)

Por tanto, a través de la performance se refuerza la communitas y se pone de manifiesto el drama social. Sociedad y comunidad son la base del significado de la puesta en escena, en la que se refuerza y se ponen en valor las experiencias de los romeros, pero también las jerarquías sociales, las relaciones personales, las concepciones de salud y

\footnotetext{
${ }^{4}$ Jeremy Bentham (1780) define el juego profundo como un juego con apuestas tan altas que ninguna persona racional se involucraría en él. Puede ser irracional jugar este juego ya que en esta apuesta hay mucho que perder y se dan altas probabilidades de que devenga en fracaso.
} 
enfermedad, lo sagrado, lo festivo y lo ritual. Este significado profundo de la cultura es representado y experienciado en un locus ritual concreto, estructurado y acotado, que se repite y se renueva de forma periódica. Los actores sociales experimentan y significan la romería desde estos parámetros, donde la performance está vinculada fuertemente con la cultura, la identidad y la comunidad.

En una perspectiva actual, intercomunicada a distintos niveles, Marc Augé (2018) reflexiona acerca de las paradojas de la movilidad, haciendo hincapié en los cambios en los conceptos de identidad y alteridad a causa de la globalización de los medios de comunicación. Explica que su trabajo consiste en «poner en términos de espectáculo las diferencias y hacer de ellas productos de consumo». El primero de estos productos es el consumo turístico. Por ello, la cultura también se torna producto de consumo y, los individuos, consumen experiencias culturales (ya sean propias o ajenas). Esta concepción de la experiencia o de la puesta en escena turística, por tanto, se aleja de la consideración de drama social planteada previamente, pero se ajusta a una realidad presente en las celebraciones actuales.

Este consumo de la cultura en términos de experiencias turísticas supone la búsqueda de elementos de alteridad (o bien diferentes, o bien exóticos) o identidad (de unión o asimilación). El turismo se convierte en una expectativa más de los individuos $\mathrm{y}$, debido a la globalización de los medios de comunicación, la experiencia deja de ser personal, para ser prontamente compartida y difundida. Si a esto le unimos que las redes sociales se han vuelto primarias en el comportamiento habitual de los individuos, la separación entre lo digital y lo no-digital (o real), es bastante difusa (Hine, 2004), creando «un mundo de información que vuelve cada día más dudosa la distinción entre realidad y ficción» (Augé, 2018: 16-17).

En la misma línea, centrándose en las interacciones derivadas del uso de Internet y las redes sociales, el filósofo Byung-Chul Han (2017) postula que la hiperconectividad nos hace esclavos, y no amos. El poder actual es seductor: se mueve por las redes sociales, azuzando la emoción de los individuos, creando una falsa ilusión de libertad en el que la gente teclea y se posiciona digitalmente, pero no actúa. Esto supone que la comunicación no se basa en escuchar o dialogar, sino en mostrar. Y, por ello, los individuos libran una batalla silenciosa en la que pugnan por distinguirse, por mostrarse en opinión o en imagen. Una de las fórmulas de hacerlo es mostrar su ocio a los demás.

Las narrativas que se muestran en los medios digitales son intencionales (como cualquier otra narrativa). No obstante, tienden a lo visual para reforzar los posicionamientos individuales; pero también a la semiótica, para garantizar la rápida transmisión de sentimientos, emociones, etc. Ambas formas de expresión son utilizadas de forma conjunta: los breves textos descriptivos (las opiniones, comentarios, exposiciones, etc.), se acompañan con fotos, videos, gifs y toda suerte de fórmulas visuales de corta duración; también se usan emoticonos más o menos explícitos (y prediseñados) así como stickers y diferentes modos de codificación semiótica de sentimientos y emociones. En el espacio virtual, la comunicación ya no es logocéntrica: la imagen sustituye a la palabra, se representa una idea y con ella, también, se narra un discurso dirigido (en el sentido de Michael Foucault 1970, 1980), que es más o menos explícito y consciente para los interlocutores.

Para Michael Foucault (1979), en la modernidad y postmodernidad, este oculocentrismo derivado de la proliferación de imágenes en periódicos, revistas, etc., «se convierte en una herramienta y un medio por el que se ejerce el poder en la sociedad.» (Banks, 2010: 34). En este sentido, los controles de vigilancia modernos, más o menos 
visibles y más o menos intuidos por la población (desde cámaras de vigilancia a redes sociales) son un moderno panóptico en el que se reproduce el poder Michel Foucault $(1970,1980)$.

Marcus Banks (2010: 34) diferencia entre «narrativa interna y externa» de las imágenes. Así, la interna responde a la pregunta básica de descripción de la imagen (qué objetos, personas, etc., aparecen en ella) mientras que la narrativa externa es la historia que se construye respondiendo a preguntas más complejas, sobre la intencionalidad de la foto, la del autor, sobre el contexto en donde fue tomada, etc.; teniendo en cuenta, por tanto, personas y acontecimientos: «en pocas palabras, considerando la imagen como un nodo o un canal en una red de relaciones sociales humanas.»

La imagen como representación visual, continua Marcus Banks (2010: 35-36), tiene tres propiedades adicionales (Chaplin, 1994): su forma está dictada por un conjunto de códigos o convenciones, se inserta en procesos sociales (los refleja y constituye) y, finalmente, tiene algún tipo de fuerza intencional (agencia) lo que supone estar dirigida a alguien o algo (observador, consumidor o usuario). Bajo esta perspectiva, las imágenes nacidas para ilustrar las noticias (personales o informativas) también se conciben para provocar la reacción de los usuarios; se diría que obtienen una agencia secundaria (Gell, 1998), en el sentido de que las personas que las realizan transfieren su intencionalidad a la fotografía. Son herramientas para un fin, más o menos consciente,

porque un nexo de relaciones humanas imbuye al objeto con una agencia aparente, con independencia de los deseos de cualquier individuo particular. La idea de que las imágenes, bien por derecho propio o como herramientas de otros humanos, tienen agencia, implica que las imágenes «trabajan». (Banks, 2010: 31)

Por tanto, las imágenes que utilizan los diarios, blogs, páginas de noticias o usuarios en general, trabajan para los demás internautas: transmiten una idea, más allá de una presencia en el lugar. Junto con los titulares o pies de foto que acompañan a cada imagen se crea una narrativa, más o menos posicionada, que induce una reacción en el observador. Desde esta consideración, aquellas personas que navegan entre redes sociales, blogs y múltiples plataformas informativas, recogen esta información y, sobre ella y su experiencia, manifiestan sus sentimientos en forma de comentario, likes, emoticonos, etc.

Por otro lado, cuando los usuarios virtuales muestran o comparten de forma visual sus propias vivencias, éstas se manipulan e idealizan, ya que el espectador virtual asume códigos sin diálogo directo: a partir de la interpretación de la imagen mostrada, crea o imagina el contexto, las relaciones y las dota de significado. Esta manipulación intencionada de las imágenes está dirigida a idealizar las vivencias mostradas. En este sentido, como dice Byung-Chul Han (2017), las redes sociales solo quieren presentarnos aquellas secciones del mundo que nos gustan; es, lo que el autor llama la «tiranía de lo igual». Y, bajo esta perspectiva, se entiende la afirmación del mismo autor de que «los turistas no tienen experiencias que impliquen una trasformación y un dolor. Se quedan igual. Viajan por el infierno de lo igual» (2017: 58). Reproducen patrones que se acomodan a este código visual, trabajan para mostrar un contexto idealizado de experiencias.

A partir de todo lo anterior, por tanto, cabe preguntarse ¿cómo se proyecta la experiencia ritual de Santa Marta de Ribarteme en el espacio virtual? ¿se reproducen los mismos valores del drama social y de refuerzo de la communitas? O, por el contario, ¿se invierte la codificación para resignificarse en una puesta en escena de consumo turístico? 
Y, en cualquier caso ¿cómo afecta todo ello a la celebración de la romería de Santa Marta de Ribarteme?

\section{La Romería de Santa Marta de Ribarteme}

Antes de proceder al análisis del significado de la experiencia de cada parte implicada, señalaré brevemente las particularidades del estudio de caso que guiará la reflexión de este texto. He seleccionado la romería ${ }^{5}$ de Santa Marta de Ribarteme por su particular exposición de la devoción religiosa y porque, a mi entender, condensa múltiples facetas del significado vital, comunitario y religioso de la experiencia ritual gallega.

En su definición más básica, las romerías son peregrinaciones de los devotos a un santuario. Por lo general se componen de distintos momentos de celebración comunitaria (Rodríguez Becerra, 2009; Velasco, 1982): la preparación o camino al santuario, la parte central en la que se lleva a cabo la liturgia católica bajo la advocación del santo o santa protectores (parte en la que toma significado el ritual propiamente dicho) para, una vez completada, pasar a la comensalidad o celebración profana (fiestas patronales, meriendas campestres, etc.).

Esta celebración se localiza en el pueblo de Ribarteme, en el sur de la provincia de Pontevedra, muy próximo a la frontera de Portugal. Es una fiesta periódica, que coincide con la onomástica de Santa Marta, el 29 de julio; además, como es habitual en muchas romerías gallegas, se enmarca dentro las fiestas patronales del pueblo. Según el relato bíblico, Santa Marta es la hermana de Lázaro; fue ella quien intercedió ante Jesucristo, cuando su hermano murió, para que obrara el milagro de que le devolviera la vida. Por eso se considera a esta Santa la intercesora en los momentos críticos de la vida, siendo la protectora de los desamparados o, más concretamente, de los desahuciados ${ }^{6}$.

La datación histórica de esta celebración es difusa. Pese a que hay fuentes que defienden que se celebra desde el siglo XII, otras sitúan el comienzo de esta práctica en la Edad Media. No obstante, la primera referencia escrita a la celebración de esta romería data de 1700.

La característica principal de la romería de Ribarteme es que los devotos realizan «una procesión de cadaleitos ${ }^{7}$ » o desfile de ataúdes. Algunos de los devotos u «ofrecidos», (llamados así porque se ofrecen a la Santa para que interceda en sus peticiones), tras la misa solemne, se introducen en los ataúdes y realizan así la procesión penitente alrededor del santuario (figura 1). Por ello esta romería es denominada coloquialmente como la «romería de los no-muertos» o «de los que han vuelto a la vida». No obstante, como veremos a continuación, esta percepción deriva principalmente de la forma en que la romería se presenta en los medios de comunicación, más que en la propia concepción de las personas devotas.

Esta diferenciación en los términos de «no-muertos» o de los que «vuelven a la vida» es esencial para entender la polaridad en la percepción de los distintos usuarios: la primera tiene un tinte de morbosidad tétrica; la segunda, se aproxima al sentimiento de intercesión que solicitan las personas devotas que participan en ella.

\footnotetext{
${ }^{5} \mathrm{Si}$ bien no voy a entrar en la distinción entre fiesta popular, romería o fiesta tradicional, pues en este caso los límites que separan estos conceptos son difusos, utilizo el término romería por ser el más común para referirse a esta celebración por los diferentes actores sociales.

${ }^{6}$ El significado de desamparo o desahucio aquí se entiende a la ausencia de salud causada por enfermedades graves o mortales.

${ }^{7}$ Término gallego para referirse a los ataúdes.
} 


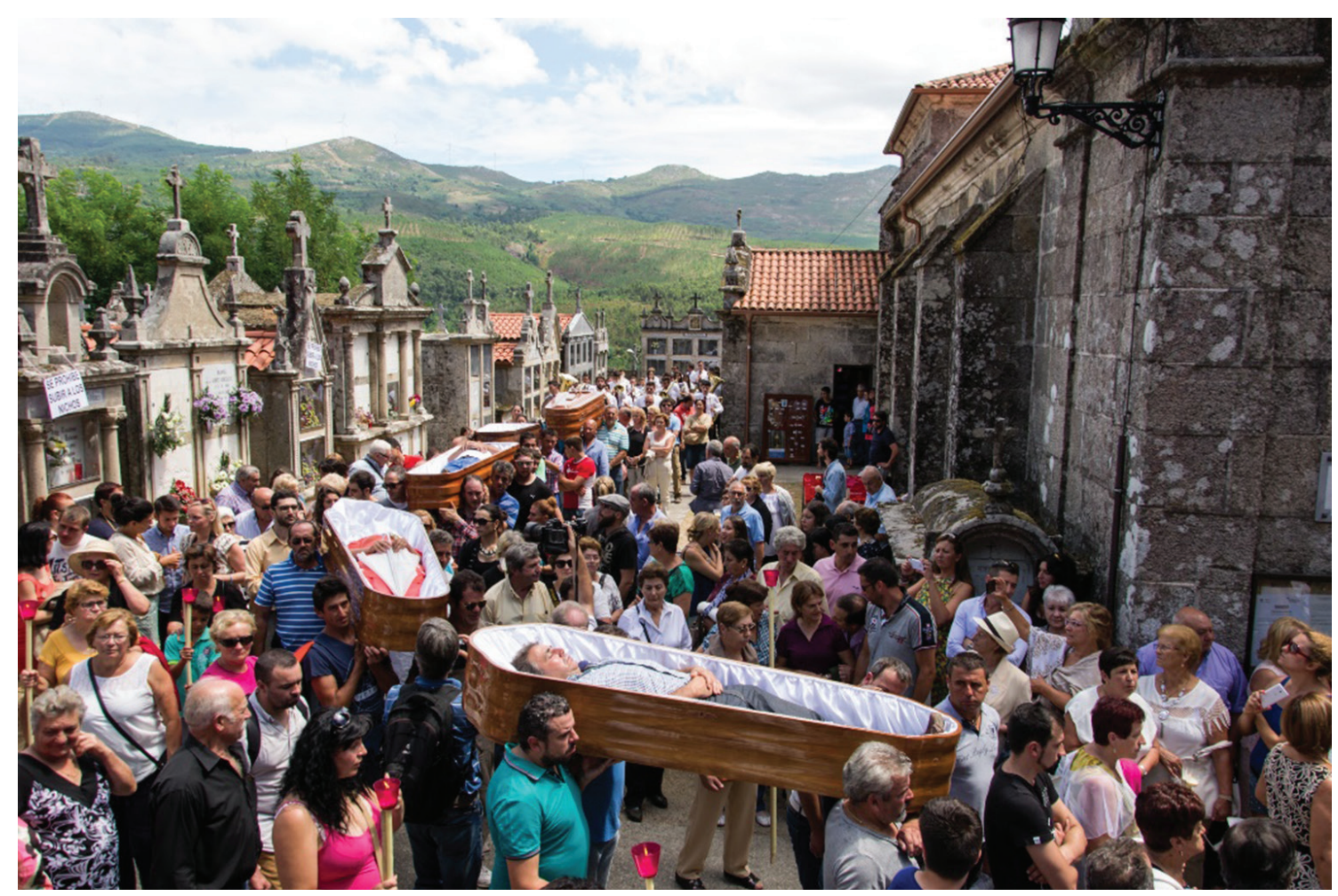

Figura 1. La característica principal de la romería de Ribarteme es que ciertos devotos participan en la procesión tras la misa solemne dentro de ataúdes, porteados por otros romeros o familiares, como ofrenda o petición ante Santa Marta para que medie en procesos de salud-enfermedad. La procesión se inicia en la iglesia, recorre el entorno del santuario atravesando el espacio del campo donde se celebran las fiestas patronales, rodea la iglesia y finaliza en el interior del santuario. En la imagen se muestra el último tramo de la procesión en el atrio. 2015.

La praxis de esta romería no es única ${ }^{8}$ en Galicia, ya que las celebraciones de Santo Anxo en Moaña (Pontevedra) y «Os Caladiños ${ }^{9} »$ en Pobra do Caramiñal (A Coruña) son similares. Pese a que estas romerías se realizan en zonas más pobladas, con mejores accesos, tanto a pie como en autobús o en coche particular, la de Ribarteme, sin embargo, es la más conocida. Quizá su localización, en un pequeño valle próximo a la frontera con Portugal, refuerce su carácter liminal (Turner, 1988) y contribuya a fomentar el halo de ancestralidad $^{10}$ que le acompaña. Mientras que Moaña y A Pobra do Caramiñal son poblaciones más grandes y destinos turísticos estivales, Ribarteme es un pequeño pueblo apartado. La población flotante ha provocado que las celebraciones de Santo Anxo y Os Caladiños hayan perdido devotos, así como parte de la carga ritual en aras de un refuerzo del carácter festivo.

Sin embargo, la romería de Ribarteme en los últimos años ha alcanzado una gran proyección mediática, tanto a nivel nacional como internacional; el punto de inflexión se produce con la publicación de reportajes sobre la celebración en diferentes medios de

\footnotetext{
${ }^{8}$ Frente a lo que se defiende, como se verá, de forma reiterada por diferentes medios de comunicación, ya sea como reclamo turístico o como forma de legitimación del ritual.

${ }^{9}$ Palabra gallega para designar a los que están callados o que van en silencio.

${ }^{10}$ Este es un calificativo común a la hora de promocionar la singularidad de esta romería en los medios de comunicación, como se verá más adelante. Uso aquí el término para reflejar la carga simbólica asociada a esta celebración.
} 
comunicación internacionales de cierto prestigio, como la revista National Geographic (2013) y el periódico inglés The Guardian (2008). Éste último periódico publicó una lista de celebraciones extrañas ${ }^{11}$ en la que la romería de Ribarteme se reseñó en el segundo puesto. Desde entonces, a nivel de promoción turística, se han repetido las referencias a esta lista, alimentando la singularidad o rareza. Es habitual, como se verá más adelante, que se refieran a esta celebración como «única» y se vincule al mantenimiento de una mayor centralidad en sus prácticas religiosas, lo que refuerza la percepción de esta celebración con la inmanencia ${ }^{12}$ del ritual.

La imagen de Ribarteme, por tanto, trasciende el ámbito local para ser reproducida como una práctica reseñable, fuera de lo normal, en diferentes sociedades y culturas. Puede que esta reproducción no se interprete de igual modo en los distintos países en los que se muestra; no obstante, el interés reside en conocer cómo se interpreta a nivel local, para así detectar las tensiones generadas por la forma en que se difunde la imagen del ritual.

Un observador externo, (presencial o virtual), que desconozca el propósito de la ceremonia, puede malinterpretar tanto las prácticas religiosas como la finalidad personal de los actores sociales que participan en ella. Los ataúdes (figura 1) evocan una asociación directa con la muerte; concretamente, con los ritos fúnebres previos a los entierros. En algunas zonas de Galicia todavía se transportan a hombros desde la casa de la persona finada al cementerio, en compañía silenciosa de familiares, vecinos y amigos. La asociación visual entre ambos ritos, el de mediación en la enfermedad y el fúnebre, es inevitable. Esta interpretación emocional conduce a asimilar la experiencia en ambos ritos: la fuerte asociación visual entre los ataúdes, los porteadores, la gente congregada a su alrededor, las expresiones serias y de dolor, etc., irremisiblemente evocan a experiencias de muerte, de espacios fúnebres, de emociones de tristeza. Y, aquí, surge la distorsión en la interpretación de la celebración, ya que, en realidad, lo que se está celebrando en la procesión de Santa Marta de Ribarteme, es la vida.

Esta concepción vitalista de la celebración se refleja en las plegarias o coplillas que cantan los romeros durante la procesión: «Virgen Santa Marta, reina de la gloria, todo el que se ofrece, sale con victoria», "Virxen Santa Marta, estrela do norte, que lle deu a vida ó que estivo á morte» ${ }^{13}$.

Ambas son plegarias de esperanza, no de dolor, que manifiestan la intencionalidad del ritual para los devotos participantes: el sacrificio personal para solicitar la mediación de la Santa para reestablecer un proceso de enfermedad. O, lo que es lo mismo, la búsqueda desesperada de apoyo para volver a la normalidad, demostrando la firmeza de la intención a través de un acto extremo, que produce desazón en quien lo realiza y en quien lo observa.

La procesión es una parte de las celebraciones de ese día, aunque también es el momento del ciclo festivo de mayor afluencia. En los días previos a la celebración, se

\footnotetext{
${ }^{11}$ El artículo, publicado el 28/06/2008 se titula «Five best... weird festivals» cuya traducción sería «Los cinco mejores... festivales extraños».

${ }^{12}$ Como se verá en los epígrafes siguientes, la proyección de la romería a través de Internet (tanto diferentes agencias de noticias, como la propia web sobre Ribarteme) parte de la clasificación de la celebración a partir de su singularidad, calificándola, por ejemplo, como exótica o ancestral. Estas denominaciones alimentan una percepción esencialista de conservación del ritual, reforzando e idealizando la idea de invariabilidad de la celebración e inmanencia del ritual.

${ }_{13}$ «Virgen Santa Marta, estrella del norte, que le devolvió la vida al que estuvo a las puertas de la muerte» [Traducción propia].
} 
organiza la participación de los devotos, especialmente de aquellos que irán dentro de los ataúdes. Se suelen alquilar o comprar previamente, para tenerlos listos para la procesión tras la misa solemne. El día de la celebración, el 29 de julio, se colocan en el lateral derecho de la Iglesia, en el atrio, precintados con una cuerda de seguridad, señalados con los números que previamente han sido asignados a las personas ofrecidas.

Durante toda la mañana hay misas, pero la procesión se realiza tras la de $12 \mathrm{~h}$. La duración del recorrido apenas es de unos 15 minutos, siguiendo el mismo itinerario: sale de la iglesia, recorre el campo de la fiesta y vuelve al atrio, donde rodea la iglesia para, finalmente, terminar en el interior de la misma. Cuando la procesión finaliza, empieza la parte «profana» de la celebración de las fiestas patronales, con la comida campestre y la verbena. En los alrededores del Santuario hay toda suerte de tiendas provisionales con velas, exvotos, relicarios, productos religiosos; comida, bebida, ropa, juguetes; casetas de feria, barracas, etc. Todo es parte de la misma celebración, no obstante, cada momento tiene su relevancia particular.

\section{EL LOCUS RITUAL: LA CONFLUENCIA DE DOS EXPERIENCIAS IN SITU}

En el espacio de celebración de la romería podemos distinguir dos grupos de actores sociales principales: aquellos que participan directamente en la ceremonia religiosa (devotos) y los que acuden para observar el ritual (espectadores ${ }^{14}$ ). Evidentemente, todos participan, en mayor o menor medida, de la celebración festiva, pero separo ambos tipos ${ }^{15}$ para mostrar las visiones dicotómicas que puede adquirir la experiencia en el locus ritual. Devotos y espectadores coexisten en el mismo espacio; no obstante, sus percepciones sobre la celebración, su significado, así como su experiencia ritual, son muy diferentes. Su grado de participación directa o indirecta en el ritual, también supone una forma de diferenciación de cómo significa cada conjunto la celebración.

El grupo que tiene una participación directa es la de los devotos. Éstos son de dos tipos: los penitentes y los acompañantes. Dentro de los penitentes se distinguen, por un lado, los amortajados y, por otro, los poxos. Los amortajados son los que participan de forma más evidente en la procesión: o bien dentro de los ataúdes o bien vistiendo una mortaja, que es una suerte de sudario blanco, semitransparente, que se pone sobre la ropa (figura 2); ésta, al igual que los ataúdes, se puede adquirir o alquilar en el Santuario. Este es el grupo central por medio del cual se manifiesta la praxis ritual: los ofrecidos que piden favores a la Santa a través de su esfuerzo. Como en otras romerías similares, se consideran dentro de esta categoría a aquellas personas que realizan el recorrido a pie, bien descalzos, bien de rodillas, las que portan velas encendidas o exvotos de cera. Desde un punto de vista visual (figura 2), se identifican fácilmente y se reconocen como los actores principales del ritual.

El esfuerzo, los exvotos, las mortajas, las velas, los pies descalzos, etc., forman parte del diálogo sobrenatural que se establece entre el devoto y la Santa, que se formula a través de la promesa. Este tipo de comunicación, como apunta Salvador Rodríguez Becerra (1999: 130-131) se fundamenta en un sistema de reciprocidad basado en favores, cuya relación diádica es consustancial al fenómeno votivo y que se guía por la secuencia «prometer-recibir-dar». Por medio de la promesa, ya sea en forma de exvoto, ya sea en

\footnotetext{
${ }^{14}$ Se utiliza el término espectadores y no observadores, para resaltar la condición intencional de no participación directa.

${ }^{15}$ Evidentemente podrían incluirse más, pero estos son los principales para entender las experiencias y expectativas que cada grupo tiene sobre la celebración.
} 


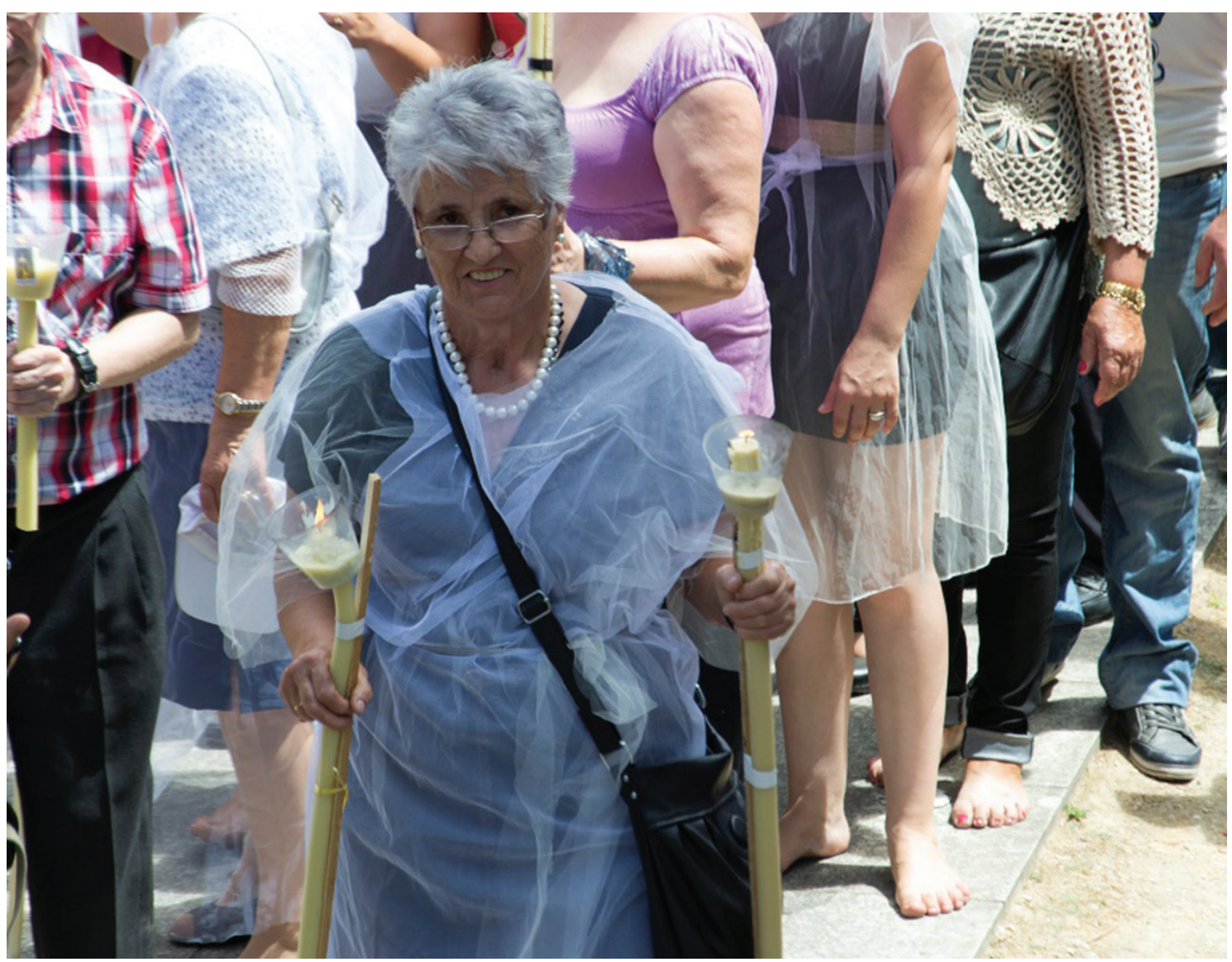

Figura 2. Además de aquellos devotos que siguen la procesión dentro de los ataúdes, otros penitentes u ofrecidos caminan descalzos, visten mortajas, presentan exvotos, cirios, etc. En la imagen se aprecian varias personas vestidas con la mortaja, así como las que realizan descalzas el recorrido de la procesión. 2015.

forma de esfuerzo, se crea una estructura de relaciones asimétricas entre el oferente y la figura sagrada, bajo la cual se representa el sacrificio individual para conseguir la gracia.

La ofrenda de su esfuerzo es la que lo pone en valor ante la Santa; por eso realizan un acto de fe, catártico e incómodo que manifiesta la firmeza de su petición. Este favor que solicitan puede ser para el momento presente (pendiente aún de resolver) o ya haberse cumplido (haberse pedido en el pasado y estar ya resuelto favorablemente). En este último caso, se renueva la promesa para agradecer a la Santa la gracia; en algunos casos, la práctica se repite de forma periódica cada año, dependiendo de la petición realizada por la persona ofrecida en el momento de solicitud de intercesión.

Por tanto, el rito tiene dos significados para el ofrecido: por un lado, los que hacen un esfuerzo para introducirse en el ataúd como muestra de esfuerzo personal y ver cumplida su solicitud; y, por otro, los que, una vez han logrado el favor de la Santa, se introducen en el ataúd de nuevo para agradecerle su intercesión.

La lógica que rige esta práctica es que cada ofrecido ha comprado o alquilado el ataúd, pero no lo va a necesitar (porque Santa Marta intercedió y el devoto recobró la salud). Es en este marco conceptual en el que se entiende que esta romería celebra la vida y no la muerte; por eso, para las personas conocedoras del ritual, no existe una asimilación entre el desfile de ataúdes y los funerales, sino que se entiende como un paso intermedio, a través del sacrificio personal, para evitar la muerte. 


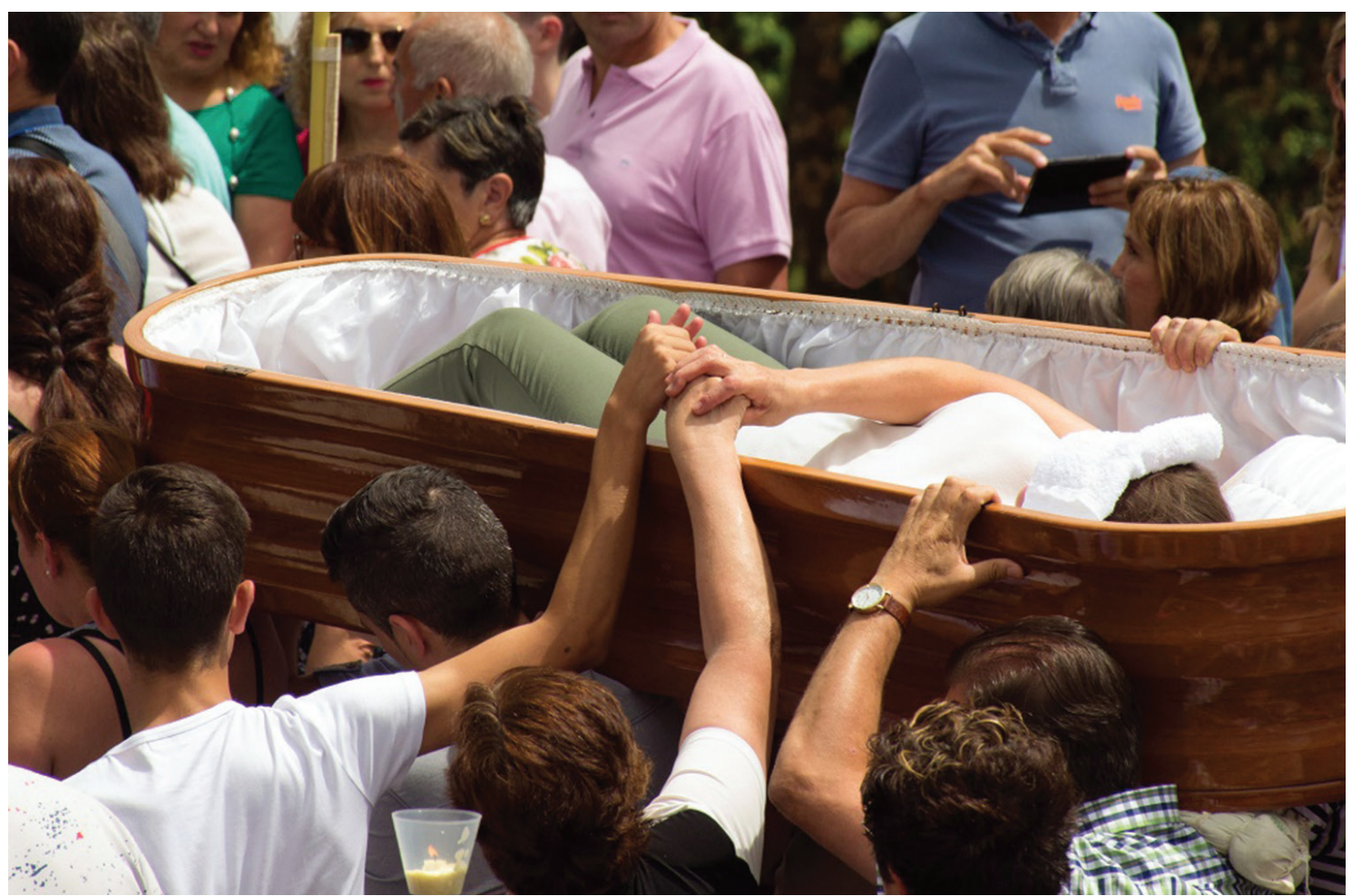

Figura 3. Los poxos o porteadores se turnan para llevar a hombros a los ofrecidos a para apoyarlos durante el proceso ritual; todos los romeros tienen un lugar central en la procesión. El sacrificio personal se apoya en la comunidad logrando un refuerzo de los vínculos identitarios. 2018.

Pero, ante todo, la base del rito es la comunidad y en ésta adquiere significado. Especialmente en la solidaridad entre penitentes. Otros devotos ayudan a los ofrecidos en sus diferentes prácticas: las personas que portean los ataúdes (denominados poxos) son, o bien familiares de la persona a la que portan, o bien penitentes que también han solicitado la mediación de la Santa. Portar el ataúd también requiere de un esfuerzo físico e incómodo pero, además, este subgrupo facilita el cumplimiento del rito para los ofrecidos de los ataúdes, promoviendo la colaboración entre devotos.

En este grupo de porteadores, también se expresa el orden comunitario ya que poxo significa tanto porteador como postor. Los poxos se relevan a lo largo del recorrido para llevar a hombros los distintos ataúdes, así como la imagen de la Santa. Los turnos se organizan en orden del donativo económico previamente ofrecido al santuario. Y, hasta hace unos años, antes de la celebración se producía una puja económica para lograr portar la imagen de la Santa en el momento final de la procesión e introducirla en la iglesia; esta acción dotaba de un estatus particular a la persona que lo realizaba, logrando un reconocimiento social importante a nivel comunitario.

Finalmente, dentro del grupo de devotos, también se integran los acompañantes, que son los romeros que acompañan la procesión y la liturgia religiosa, pero que no tienen un papel principal en la misma. Es un momento festivo, de celebración; pese a que hay dolor entre los penitentes (no solo por el esfuerzo físico, también por las vivencias y experiencias individuales que los llevan a participar), también hay un fuerte sentimiento de consuelo, acompañamiento y alivio (figura 3). La comunidad se apiada del penitente, le apoya y le acompaña en sus experiencias personales, siendo ésta la finalidad básica del ritual, que le da forma y significado. 
El segundo grupo de análisis, que no participa directamente del rito religioso, es el de los espectadores o turistas. Como es una fiesta patronal, Ribarteme recibe muchos visitantes ${ }^{16}$, por lo general, vecinos de los pueblos de los alrededores, o familiares que acuden para participar en la parte «profana» de la fiesta. No interfieren en los acontecimientos y se caracterizan por ser meros observadores del ritual. Por lo general, siguen la procesión desde la distancia aprovechando para curiosear, comentar el número de ataúdes, indagar sobre los ofrecidos (especialmente sobre los de los ataúdes) y sus motivos. Este grupo, aunque participa subsidiariamente en el ritual, también muestra el refuerzo comunitario de esta celebración.

Dentro de este grupo de espectadores del ritual se incluyen los turistas. Se separa como subgrupo para recalcar su condición externa o ajena. Esta separación no es únicamente geográfica, sino de relación con la comunidad. Inicialmente acuden para observar cómo se desarrolla la procesión, sin intención de participar directamente en ella. Su papel (al menos inicialmente) es el de meros observadores que buscan saciar su curiosidad y como fórmula de entretenimiento. Por lo general, acuden a Ribarteme entorno a la hora en que se celebra la procesión y aguardan expectantes en las inmediaciones del templo; recorren la zona buscando el mejor sitio para observar la procesión, compran algún recuerdo en los puestos provisionales de la fiesta y, concluida la procesión, se marchan. La mayoría solo acuden para ver esta celebración una única vez o, si repiten nuevamente, espacian varios años las visitas.

Pese a que su intención es no participar en el ritual, en algunos casos sus prácticas interfieren en el desarrollo del mismo ${ }^{17}$, lo que rompe la intencionalidad inicial. Al percibir la celebración como un elemento de entretenimiento, también se llevan a cabo acciones que, en el contexto de la celebración, podrían considerarse malas prácticas para el desarrollo del ritual.

La más extendida y, quizás, la más agresiva para con los devotos, es su constante registro fotográfico; la finalidad de este registro no solo es la documentación del evento sino, en muchos casos, la búsqueda del detalle superfluo. En la zona, como ya se comentó, hay una amplia presencia de medios de comunicación, que graban y fotografían a los devotos durante la procesión. A ellos se suman aficionados a la fotografía, blogueros, etc. En los últimos años, además, hay que tener en cuenta el uso generalizado de teléfonos móviles con cámara, que hace que el registro de la celebración (principalmente de la procesión) sea intenso y esté generalizado ${ }^{18}$.

\footnotetext{
${ }^{16}$ Inicialmente se consideró la separación los visitantes en un tercer grupo. No obstante, pueden considerarse como visitantes tanto a los devotos (que acuden de todas partes de la geografía gallega) como a los espectadores (ídem), por lo que su incorporación como grupo separado podría dificultar la identificación de las experiencias dicotómicas sobre la celebración. Se incluyen aquí como parte de los espectadores a aquellos que no participan directamente en el ritual; evidentemente, los visitantes que acuden como ofrecidos o devotos (o que participan de la liturgia religiosa), están incluidos en el grupo anterior.

${ }^{17}$ Quisiera dejar claro que me refiero a un tipo de turistas muy concreto: los que llevan a cabo lo que se podría considerar como malas prácticas de actuación. No considero que los turistas sean un grupo negativo o perjudicial, como tampoco considero que lo sean los medios de comunicación. De igual modo, tampoco el mal comportamiento está generalizado y localizado solo en estos grupos. Se fuerza aquí el contraste con las categorías anteriores para mostrar los conflictos y tensiones que pueden surgir a raíz de las diferencias en la concepción de la participación en la romería y, sobre todo, por las prácticas derivadas de esta concepción desigual.

${ }^{18}$ Dado que lo que se pretende es resaltar aquellas malas prácticas que se llevan a cabo, se ha incluido en este grupo también a ciertos medios de comunicación. Si bien están presentes en el lugar por motivos
} 


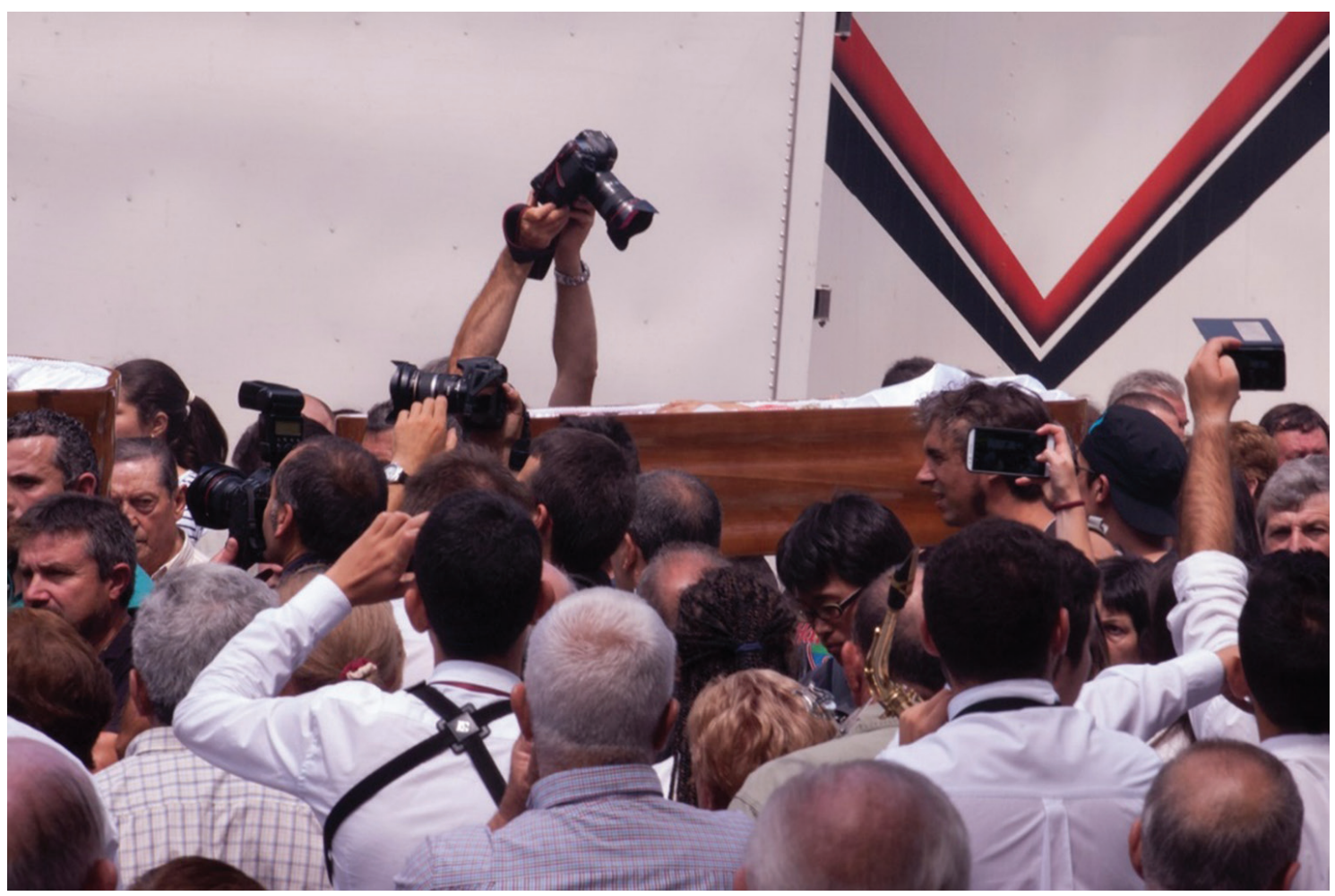

Figura 4. El constante registro fotográfico que busca retratar el primer plano de los ofrecidos dentro de los ataúdes provoca una interrupción del clímax ritual de los penitentes, forzándolos a tapar su rostro para esconderse del acoso gráfico. La mayoría de estas imágenes y vídeos serán compartidas por profesionales y aficionados en las redes sociales, blogs y portales de noticias, tanto a nivel local, como nacional e internacional. 2015.

El turista concibe la celebración como una experiencia de ocio, de distensión, etc. Como espectador, consume la puesta en escena y, los suvenires de este espectáculo, son las fotos. Por eso parece haber una competición generalizada por captar la imagen de los ofrecidos dentro de los ataúdes, llegando a niveles cercanos al acoso. Se vulnera constantemente la intimidad de los romeros que, se ven invadidos por múltiples cámaras de fotos que tratan de registrar su cara (que no deja de ser un detalle superfluo).

El problema de esta excesiva documentación gráfica a la que se somete a los devotos es que influye directamente sobre la participación de los romeros. El seguimiento y registro de cada detalle de la procesión alcanza en algunos puntos una intensidad que rompe el clímax de intimidad y penitencia que envuelve la praxis de los devotos. Durante los trabajos de investigación pude registrar como cada persona dentro de un ataúd era fotografiada por más de diez cámaras a escasos centímetros de su cara (figura 4). Por eso muchos devotos se cubren ${ }^{19}$ con abanicos, gafas, sombreros, etc., conscientes de que van a ser fotografiados, grabados y difundidos sin su consentimiento.

Hay que recordar que ese momento particular de la celebración es un acto íntimo, personal, al mismo tiempo que se construye comunitariamente. Esta construcción se fundamenta en el respeto por el ofrecido y en el acuerdo tácito de acompañarlo, de

laborales, su presencia desencadena una serie de acciones que se extienden al grupo de turistas; esta interrelación provoca cierta confusión para delimitar a ambos grupos.

${ }^{19}$ Este uso de objetos para cubrirse es aprovechado por los fotógrafos para mostrar gráficamente el contraste de los vivos dentro de los ataúdes. Esta imagen es recurrente en los diarios de noticias. 
solidarizarse con su petición a la Santa y de amortiguar levemente su penitencia sumando la propia.

Durante la procesión, este clímax ritual se interrumpe de diferentes maneras. Es habitual ver a los reporteros de las televisiones, tanto locales como internacionales, entrevistar en directo a los ofrecidos, preguntando por sus motivaciones, sentimientos e impresiones en el mayor momento de intimidad y esfuerzo personal del ritual. La intervención externa se ha normalizado hasta tal punto que, en 2015, pudimos registrar como un particular, aficionado a la fotografía que buscaba captar el momento, ordenaba a la cabeza de la procesión que se detuviera, en mitad del recorrido, para poder tomar la imagen con calma.

Esta masificación del registro gráfico está dirigida principalmente a mostrar la experiencia del turista; que, a su vez, quiere transmitir a otras personas lo que está viviendo en ese lugar. Y lo hace eligiendo una narrativa personal, condicionada y dirigida para no ser descriptiva, sino claramente intencional. En algunos casos es meramente informativo, en otros se trata de evidenciar simplemente que se estaba presente $\mathrm{y}$, en otros, se busca mostrar un espectáculo. Como se verá en el siguiente epígrafe, esta forma de transmitir su experiencia repercute en cómo se interpreta el significado del ritual en aquellos que no están presentes en la romería, es decir, los que observan desde el espacio virtual.

Otra de las tensiones comunes se deriva de la búsqueda de lugares para seguir la procesión o para tomar imágenes. En los últimos años se ha restringido el acceso a determinadas zonas y se han habilitado espacios específicos para los medios de comunicación frente a la puerta de entrada al Santuario. No obstante, los espacios habilitados no son suficientes. En Ribarteme, como es habitual en Galicia, los cementerios parroquiales rodean el atrio de las iglesias. La gente se sitúa en lo alto de las tapias y en los muros del cementerio. Incluso, hay carteles que prohíben subirse a los nichos; esto llama la atención de algunos romeros, que conciben el acto de trepar por estas estructuras como una falta de respeto para familiares y difuntos, amén de poner en riesgo el patrimonio material.

Para rebajar las tensiones entre espectadores y devotos, buscando que ambos puedan participar de la celebración, se construyeron unas amplias gradas de hormigón en el recinto, delante de las cuales transcurre la procesión. La finalidad de esta estructura es concentrar a los espectadores en un lugar desde el que observar la procesión con comodidad sin interferir en el ritual, ni poner en riesgo el patrimonio. No obstante, pese a que las gradas son amplias y están ocupadas en su totalidad, es numeroso el grupo de gente que persigue la procesión, colocándose en diferentes ángulos, durante su recorrido. Todo ello, supone interferencias en la celebración que generan tensiones entre los distintos grupos de participantes.

\section{EL LOCUS VIRTUAL: LA DIFUSIÓN DE LA EXPERIENCIA RITUAL}

En epígrafes anteriores se señaló el punto de inflexión en la proyección internacional de la romería a partir de la reseña en medios como The Guardian (2008) o National Geographic (2013). Este interés de los medios extranjeros podría ser meramente anecdótico si no fuera porque se utiliza de forma recurrente para afianzar la singularidad de esta celebración, lo que, a su vez, alimenta la proyección de la romería como reclamo turístico.

La referencia a la clasificación de The Guardian se ha convertido en una constante en los medios de comunicación que, año tras año, repiten esta cuestión como una coletilla. 


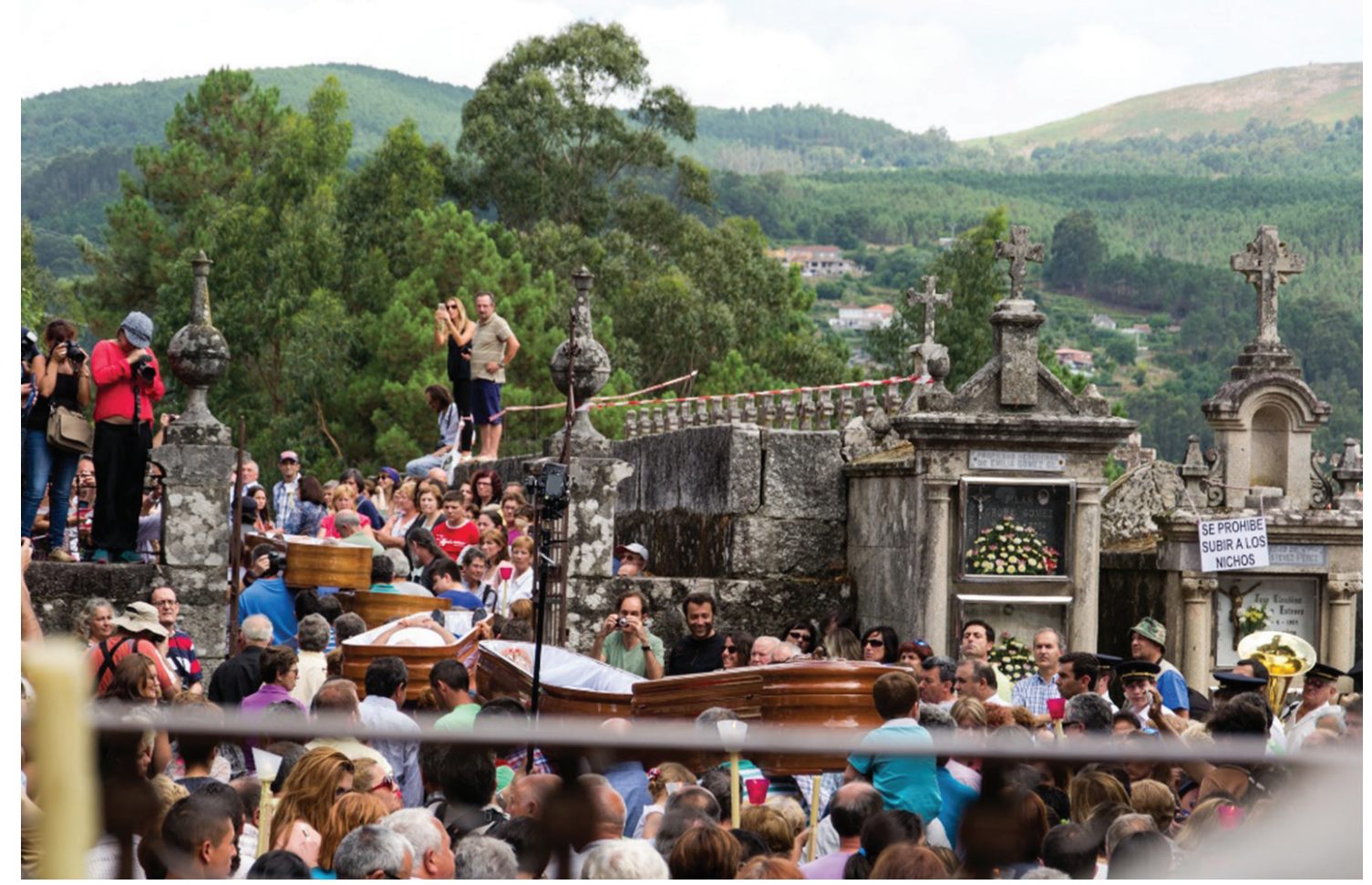

Figura 5. Pese a que hay lugares reservados para fotógrafos frente a la entrada principal de la iglesia, los asistentes se suben a muros y tapias para observar la procesión y registrarla gráficamente. Todos los años se colocan cintas prohibiendo el acceso a los muros del cementerio, así como a los nichos, norma que se saltan de forma recurrente algunos asistentes. 2015.

Incluso el portal web dedicado a la romería de Santa Marta de Ribarteme destaca esta reseña en su contenido, de forma recurrente. Pero las referencias no se limitan a los reportajes de prensa, sino también se destaca en webs sobre turismo y folletos que informan de las celebraciones de interés de la zona. Todo ello, lógicamente, ha aumentado la publicidad sobre la romería, cuyo resultado inmediato es una mayor afluencia de visitantes, así como un notable incremento de los medios nacionales e internacionales cubriendo la procesión.

La retroalimentación entre la proyección de la romería y el incremento de medios y espectadores es constante. Entre la información de las noticias de los periódicos regionales que cubren la celebración, se incluye, además de la recurrente clasificación de The Guardian, el número de televisiones y agencias de noticias, nacionales e internacionales, presentes en la romería cada año. Esta reseña adquiere una doble finalidad: por un lado, se usa como medida de prestigio, vinculándolo a la trascendencia de la festividad (lo que refuerza el interés por la misma); por otro lado, se usa como cálculo de su proyección internacional, incidiendo sobre el largo alcance (geográfico y cultural) de la romería. Por ejemplo, la presencia de National Geographic fue recogida en los periódicos locales para recalcar su trascendencia y remarcar la excepcionalidad de la celebración, «divulgándose por todo el mundo por ser única» (Palleiro, 2013).

¿Pero, cómo se divulga la imagen de la romería a través de los portales de noticias, blogs de viajes, agencias turísticas, etc.? Y, sobre todo, ¿cómo afecta esta recurrente apelación a su singularidad y a la presencia de medios internacionales a la hora de entender la romería para los usuarios virtuales? 
La página web del santuario de Ribarteme, ha sido actualizada y rediseñada recientemente, lo que también indica el creciente interés de las instituciones por promocionar la romería. En la información se utiliza de forma habitual el término ancestral para describir la romería, destacándola como «la más ancestral de las Romerías Gallegas». Este calificativo, presente en todas las secciones de la web, también sirve de subtexto justificativo para solicitar el reconocimiento de celebración de Interés Turístico Nacional (objetivo a cumplir por las diferentes instituciones). La entronización de la afluencia de agencias de noticias, especialmente de los medios extranjeros, también es un hecho promocional que se difunde de forma continuada para reforzar la relevancia de la festividad. La web de Ribarteme resalta que «los medios de comunicación más importantes ya estuvieron en nuestra romería» y tiene una sección específica dedicada al registro de la romería en los medios de comunicación ${ }^{20}$.

Como anotación de interés, la web de Ribarteme enlaza a otros cuatro santuarios marianos: los internacionales Lourdes y Fátima, y los pontevedreses O Corpiño ${ }^{21}$ y A Franqueira. Muchos son los santuarios marianos en Galicia que podrían aparecer en esta lista (principalmente las celebraciones ya referidas ${ }^{22}$ ); que aparezcan reseñados únicamente los de A Franqueira y $\mathrm{O}$ Corpiño es especialmente significativo ya que, junto a Santa Marta, también son conocidos por sus singulares prácticas rituales ${ }^{23}$. Podría interpretarse que esta asociación entre los santuarios está destinada a la promoción de una «ruta turística» por las celebraciones más particulares de la zona.

El objetivo de alcanzar, a medio plazo, el reconocimiento de fiesta de Interés Turístico Nacional, supone también una importante inyección económica en la zona. En los últimos años este propósito se hace evidente en las transformaciones estructurales que se llevaron a cabo en Ribarteme. La remodelación del espacio exterior del Santuario, competencia del Ayuntamiento de As Neves ${ }^{24}$ y de la Diputación de Pontevedra, va más allá de las gradas de cemento frente al campo de la fiesta. En 2018 se anunció un ambicioso proyecto de remodelación para la humanización del entorno del santuario, que elimina parte del bosque anexo para crear espacios asfaltados. En palabras de los representantes políticos, esta remodelación está diseñada «para convertirse en un espacio moderno y atractivo [...] con un presupuesto de 200.000 euros, para potenciar el valor arquitectónico

\footnotetext{
${ }^{20}$ Curiosamente, The Guardian (tan recurrente en todas las noticas, incluso en la misma web) no aparece reseñado en esta sección. Los únicos medios extranjeros registrados son el portal de noticias The Irish Times y el blog turístico Roads and Kigdoms.

${ }^{21}$ La página web de este Santuario, también recientemente actualizada y mejorada, introduce novedades tales como descarga de una app con información del Santuario y próximos eventos, una tienda virtual en donde comprar suvenires, recuerdos, artículos religiosos y merchandising en general del Santuario. También se puede enviar una petición o rezo a la Virgen de forma virtual (que aparece registrada de forma pública en la portada de la página web), encender una vela a distancia o realizar donativos online. Estas prácticas son habituales en otros santuarios marianos, como el de Lourdes.

${ }^{22}$ Dada la similitud en la advocación, mediación y praxis con las ya reseñadas romerías de Santo Anxo de Moaña y de Os Caladiños de A Pobra do Caramiñal, sería más lógico que se vincularan las informaciones entre estas celebraciones o que, al menos, apareciesen en la lista.

${ }^{23}$ En el caso de O Corpiño (Lisón Tolosana, 1990, 2012), conocida es su vinculación con la curación de las enfermedades mentales y los espíritus o endemoniados. En esta romería, durante la procesión, la Virgen es la que pasa por encima de las cabezas de los romeros, posicionados en fila alrededor del Santuario. En el caso de A Franqueira, el ritual incluye el traslado de varias tallas de santos protectores que se desplazan desde diferentes localidades cercanas para participar en la romería; las tallas son portadas por los vecinos y, según orden, van acercándose a la Virgen de A Franqueira para saludarla: los porteadores se agachan, bajando así la talla del santo o santa visitante, mostrando respeto ante la anfitriona.

${ }^{24}$ Con apenas 3.841 habitantes según el INE (2019).
} 
del propio templo y el entorno natural que lo rodea, priorizando su uso peatonal con zonas de descanso y un mirador» (Tébar, 2018). Estas actuaciones parecen destinadas a alojar la cada vez mayoritaria presencia de espectadores. La humanización del espacio, en este sentido, supone una humanización del ritual, ya que se diseña pensando más en el visitante que en el devoto; promocionando la parte visual de la celebración, ligándola así a la concepción de espectáculo o experiencia turística.

La priorización de los espectadores sobre los devotos es una práctica extendida que suele llevar a la modificación de la celebración. Si bien este es el devenir general de cualquier festividad, hay que tener en cuenta que la interferencia, en algunas ocasiones, ha dado lugar a la desaparición gradual de la celebración o la duplicidad de la misma. En este último caso, en algunas romerías gallegas ${ }^{25}$, como relata Luis Gárate (1998: 368383) a raíz de la Romería de A Virxe do Monte (también en la pontevedresa Santa Tegra), ante la llegada masiva de foráneos que, de forma directa o indirecta, incidían sobre la celebración, derivó en la separación o desdoblamiento de la festividad, reservándose un día oficial para los espectadores y otro día particular para los locales.

Si esto llegara a suceder, en el día oficial cabría reflexionar sobre la frontera que separa la celebración con el simulacro, en los términos que señala María Jesús Pena Castro:

la fiesta, como representación de la tradición y la historia, carecería de toda autenticidad por muy verdaderos que fuesen los elementos singulares que la componen al desaparecer cualquiera de los significados originarios de la celebración [...] La autenticidad es negada por la propia recreación que sólo puede aspirar a reconstruir un simulacro de la realidad. Una vez han cambiado el tiempo, el espacio y los actores, el significado se ve alterado de forma irrevocable e inevitable. (2004: 98)

La proyección turística se ve reforzada, directa o indirectamente, por algunos medios locales que, aprovechan esta percepción de singularidad y que la romería se celebra durante el verano, para promocionarla como uno de los «Los ganchos para el turismo en el verano de la España rural». Este tipo de noticias refuerza la proyección de la celebración como un espectáculo exótico a la que asistir, casi como una experiencia programada y creada para disfrute del turista.

Son pocos los medios de comunicación que en sus crónicas sobre Santa Marta de Ribarteme reflejan la experiencia desde el punto de vista de los individuos, ya sea en primera persona o de forma grupal. Raphael Minder (2017) en un artículo para The New York Times, titula su reportaje «El pueblo donde los vivos se meten en ataúdes para agradecer que no se han muerto»; la noticia se acompaña con imágenes de Samuel Aranda, en cuyos pies de foto se relatan experiencias en primera persona, tales como: «Pilar Domínguez Muñoz participó en el ritual un segundo año porque ella quiere demostrar su gratitud por la mejoría de salud de su hija». El texto, cargado de citas y expresiones de los romeros participantes, describe el ritual y refleja la experiencia de los presentes. Si bien es un texto periodístico, trata de mostrar las diferentes posturas de los romeros, al tiempo que muestra la peculiaridad del ritual y la extrañeza del observador externo. No obstante, pese al desconcierto, no es prejuicioso ni categórico en resaltar las partes exotizantes de la celebración, ni busca el recurso fácil para atraer la atención del público por medio del

\footnotetext{
${ }^{25}$ No solo religiosas, sino de todo tipo, como por ejemplo «Os Caneiros» en Betanzos, que desde hace casi diez años celebra el «Día de la Familia» previamente a la celebración oficial de Os Caneiros; en esta nueva celebración participan únicamente los vecinos de la villa y de los pueblos de alrededor.
} 
morbo; al contrario, trata de conducir al lector hacia una comprensión del ritual o, cuanto menos, hacia una empatía con los participantes a través de sus motivaciones. El autor se toma su tiempo para entender el significado del ritual para los devotos, más allá de la puesta en escena, transmitiendo a sus lectores las pasiones humanas que lo significan.

Paradójicamente este mismo artículo fue recogido, difundido y compartido por otras agencias de noticias en las redes sociales. No obstante, pese a poner en primera persona el relato en consonancia con el texto original, caen en el morbo, como recurso fácil para difundir la noticia en sus canales. Un ejemplo es Bol Noticias (Brasil) que hace su propia traducción del título, respetando después el texto original: «Vivos se fingem de mortos em festa religiosa na Espanha»; lo mismo sucede con el blog El Observatorio Cuyano, que difunde el mismo texto, pero con el título «Un ritual donde los vivos pasan un día "muertos" como agradecimiento». Este cambio de titular invierte la polaridad del mensaje sobre el sentido de la celebración: en el original se habla de vivos que se meten en ataúdes como agradecimiento; en las adaptaciones, de vivos que fingen ser muertos.

Lo más habitual entre los portales de noticias es caer en la difusión en estos últimos términos, lo que condiciona también su interpretación por los usuarios virtuales. Esta presentación morbosa es más o menos explícita, especialmente en los medios locales; éstos juegan con el lenguaje para aunar, por un lado, llamar la atención sobre la noticia $\mathrm{y}$, por otro, ser respetuosos con los sentimientos de sus lectores, que son potenciales devotos de Ribarteme. Así, introducen las crónicas de forma aparentemente neutra, aunque siempre destacan algún elemento que sirve de reclamo; por ejemplo: «Vídeo: Así fue la romería de los "resucitados" en Santa Marta de Ribarteme, en As Neves» (El Faro de Vigo, 29/07/2018, Facebook).

Las denominaciones más habituales recogidas en las noticias de los periódicos, blogs y canales de noticias online analizados son «procesión de ataúdes», «desfile de ataúdes», «los no muertos», «los resucitados», «el desfile de los muertos-vivos», «Romería de la Muerte», «devoción tétrica», «la fiesta de los muertos vivientes» o «el festival del ataúd, que se conoce más comúnmente como el Festival de Experiencias Cercanas a la Muerte o por su nombre local: las Fiestas de Santa Marta de Ribarteme». La tan reseñada clasificación de The Guardian también la denomina como «festival de las experiencias cercanas a la muerte».

La proyección mediática del ritual a través de la muerte (y no de la vida) fomenta una imagen concreta que, evidentemente, condiciona la comprensión por parte de los lectores virtuales y dirige el discurso sobre la imagen proyectada. Sobre todo, cuando la lectura se hace de forma rápida, limitándose al titular. En las redes sociales, esta forma de lectura es habitual, lo que favorece la reproducción de opiniones por parte de los usuarios basadas en esta imagen condicionada de la romería. Y es, en este punto, donde el ritual adquiere otro significado virtual y se manifiestan nuevas tensiones entre los actores sociales.

Entre las respuestas y comentarios analizados ${ }^{26}$, se manifiestan de nuevo las perspectivas de devotos y espectadores. En el primer caso, el de los devotos virtuales, no necesariamente son personas que han acudido a la romería, sino que se suceden testimonios de afinidad religiosa o sobre la búsqueda desesperada del restablecimiento de la salud; como curiosidad, en este grupo cala fuertemente la clasificación de inmutabilidad del ritual, que utilizan para validar la práctica. En el segundo caso, entre los espectadores

\footnotetext{
${ }^{26}$ Que superan los 20.000 y que no voy a reproducir en este texto por ser, como se comentó al principio, un análisis complementario que, en la actualidad, es necesario tener en cuenta como grupo de análisis.
} 
virtuales, se dividen las opiniones entre los que manifiestan su desconocimiento de la celebración, pero les suscita curiosidad y les gustaría verla (apelando a la calificación de ancestralidad y particularidad de la celebración, pero también de exotismo); entre quienes aprovechan la noticia para exaltar la cultura gallega, aprovechando las referencias de singularidad y ancestralidad para reforzar la identidad cultural; y, por último, quienes aprovechan la noticia sobre Ribarteme para promocionar otras fiestas o lugares de interés (locales, nacionales e internacionales) que, en su opinión, son dignas de visitar.

No obstante, en el espacio virtual también está presente un tipo de participante que, por su posicionamiento, no se visualiza claramente en el locus ritual: quienes menosprecian la celebración y rechazan el ritual. Los comentarios contrarios son más evidentes en las redes sociales y en ello radica su interés. Las personas contrarias manifiestan abiertamente su rechazo y sus razones. Por lo general, este tipo de comentarios se fundamenta en la oposición a dos elementos principales: a la religión (incluyendo y, muchas veces, confundiéndola con las organizaciones religiosas) y a la forma de buscar un restablecimiento de la salud. En ambos casos los comentarios se amparan en la proyección de la imagen ancestral de la romería para, en contraposición, posicionarse en su contra.

En este sentido, el uso de este calificativo en las noticias refuerza la visión de esta celebración como fuera de lo normal o extraordinaria. La continua referencia como práctica ancestral es aprovecha por este grupo de usuarios virtuales para vincularla con la idea de «atraso» o «poco moderno». De este modo, pese a que los medios pretenden, con este calificativo, reforzar la idea de que la devoción está arraigada en la población y liturgia locales, también puede inducir a que el observador califique la práctica de supersticiosa. Cuando se entiende desde estos parámetros, los usuarios virtuales apelan en sus comentarios al viejo debate, excluyente y antagónico, de incompatibilidad entre ciencia y religión.

En este sentido, estos comentarios apelan a la inmutabilidad del ritual para clasificar la romería en un apartado exótico, morboso, extraño, supersticioso, lúgubre y tétrico; y se valen de las propias calificaciones de los periódicos para apoyar sus argumentaciones. También, extendiendo la opinión sobre los devotos, los clasifican en parámetros negativos, siendo recurrente el uso de términos como supersticiosos (enfermedad social-cultural) o locos (enfermedad individual), apartándolos de los márgenes de la normalidad y posicionándolos en los márgenes de lo socialmente aceptable (desde su punto de vista).

Esta posición está irremediablemente ligada al carácter del propio ritual, que también se aparta de lo convencional: el devoto está en un estado liminal en el que solicita la resolución de la enfermedad, con la esperanza de volver a su estado normal de salud. Pero su reinterpretación como fórmula supersticiosa y excluyente de la medicina (entendida como la única opción viable), supone la negación del significado sanador que tiene el ritual para el devoto, identificando la salud con la ciencia (o medicina) y la locura con la religión. Estas afirmaciones olvidan la miscelánea de significados personales de la religiosidad, en las que la romería no sustituye a la ciencia, sino que la complementa y apoya, como medida extra, para logar el objetivo común: recuperar la salud y el retorno a la normalidad.

Es habitual, por tanto, que se den enfrentamientos entre los usuarios virtuales que comentan las diferentes noticias. Estas confrontaciones se basan en la polaridad en los discursos de devotos y contrarios. Son una fuente de tensión continuada que da pie a discusiones y debates extensos entre los diferentes sectores que, buscando defender 
sus posturas, en la mayor parte de las ocasiones, llegan al insulto y las descalificaciones personales.

Hay un cuarto grupo ${ }^{27}$ que también provoca reacciones, a veces de apoyo, a veces de oposición, entre el resto de usuarios virtuales: quienes describen el ritual a través del humor o el sarcasmo; este grupo, por lo general (y en función de la calidad de la broma) suele ser obviado por el resto de usuarios. No obstante, es más habitual encontrar reacciones en contra que a favor, así que también es habitual que estos comentarios den lugar a enfrentamientos. Por lo general, los comentarios humorísticos suelen partir del análisis de las imágenes que acompañan a los titulares, especialmente de los que muestran el primer plano de los devotos en los ataúdes con los objetos cotidianos (gafas, abanicos, paraguas, etc.) que utilizan para ocultarse de los fotógrafos.

El enfrentamiento entre los usuarios virtuales beneficia altamente a los portales de noticias, que adquieren relevancia, seguidores y visitas que repercuten positivamente en su propio beneficio económico. Para ello buscan titulares amarillistas y fotos que reflejen el espectáculo, que no el ritual, para suscitar las reacciones de los usuarios virtuales y fomentar la polarización en la discusión. Hay portales de noticias que, además de crónicas sobre la celebración, añaden un álbum digital sobre la celebración, que también admite el registro de comentarios. Una misma imagen evoca diferentes reacciones y una discusión entre dos o más usuarios repercute en visitas, que el medio mide y monetariza. También resulta a través de los rápidos registros gráficos preestablecidos de la opinión del usuario, traducidos en «me gusta» o likes, que son una fórmula para calibrar de las reacciones personales a la noticia.

La comunidad virtual manifiesta así las tensiones, miedos, significados secundarios y experiencias del rito, verbalizadas en pequeñas discusiones, frases cortas pero cargadas de significado personal y grupal; mensajes que se dejan en el ciberespacio, sin estar dirigidos a nadie concreto ${ }^{28}$, pero con la esperanza de ser leídos. Sin embargo, nadie cuestiona la intimidad de los penitentes; se entiende que su presencia principal en la foto fija es lícita, ya que es la base sobre la cual comentar, discutir o manifestar las posiciones personales de los actores virtuales. Cuando los devotos se muestran como cabeza de noticia, especialmente las imágenes frontales, pasan de ser sujetos de acción a objeto observado, prejuzgado y criticado. Pero también, olvidado ya que la opinión es efímera: pese a que queda reflejada, se pierde en la memoria de los actores virtuales (aunque no en la memoria virtual), que pasan a otra imagen y a una nueva opinión, olvidando lo expuesto hasta que la propia red social le recuerda su propia acción tiempo después.

Es en el después, con la experiencia, cuando el usuario virtual íntimamente prejuzga sus palabras y analiza su opinión, para reafirmarla de nuevo (e incluso darle visibilidad nuevamente en el ahora virtual) o para desecharla al olvido. Por tanto, en este modo de participación virtual, la experiencia ritual se transforma; se prioriza el yo

\footnotetext{
${ }^{27}$ Un quinto grupo serían las personas que manifiestan su opinión a través de codificaciones gráficas preestablecidas (conocidos como likes) pero que no registran ningún comentario escrito y, por último, un sexto grupo, quizás el más común, el que no manifiesta ninguna opinión, ni de forma gráfica, ni escrita.

${ }^{28}$ Esta también es una cuestión interesante pues, a excepción de las discusiones más enconadas, que sí se personalizan en nicks concretos (y no en personas concretas), la interacción entre el resto de los usuarios es efímera, ya que los comentarios suelen ser textos breves e indirectos; mensajes lanzados al aire para que los lea alguien indeterminado.
} 
individual (mi opinión) frente a la acción grupal o la personal del otro. Parafraseando a Marc Augé (2018), en este caso, la participación es la ilusión y la promesa.

Finalmente, me gustaría aclarar que, evidentemente, la participación virtual no solo se lleva a cabo a través de las noticias o comentarios. La gente se informa a través de Internet, busca datos relevantes sobre la celebración, cuándo se celebra, su historia, etc. La presencia virtual necesariamente facilita la difusión del mensaje y la visibilización de la celebración. Algunos de los santuarios han actualizado sus webs para ofrecer información y servicios online que trascienden el locus ritual. Cualquier persona, en cualquier parte del mundo, y en cualquier momento, puede, por ejemplo, mandar una petición online a la Virgen de O Corpiño para que medie en procesos de salud, solicitar que se encienda una vela con una petición particular en Lourdes o comprar online un recuerdo con la imagen de la Virgen de Fátima para regalar a un familiar. Y todas estas acciones, si bien de forma marginal, son parte de la praxis actual.

\section{Conclusiones}

La experiencia y significado que adquiere el ritual que tiene lugar cada año en Santa Marta de Ribarteme cambia en función del espacio en el que se desarrolla, de la posición de los individuos con respecto a la celebración y de la manera en que participan. El espacio físico y el virtual están altamente interrelacionados y, en la actualidad, es preciso atender a ambos para conocer cómo se proyecta la celebración fuera del locus ritual, sobre todo y, muy especialmente, en el amplio y complejo entorno virtual.

Hemos visto como, desde los medios de comunicación, de todo tipo, presentes en el espacio virtual, se magnifica y manipula las narrativas sobre la celebración, proyectando una imagen vinculada con la muerte. También sobre el abuso de calificaciones que reseñan su singularidad, entendida como exótica, única e inmutable. Y, como con todo ello, se busca el morbo como reclamo para provocar reacciones en los usuarios, que difunden e incrementan las visitas, en beneficio de los portales web.

Si bien es cierto que la celebración de Ribarteme es llamativa y se presta a este tipo de interpretaciones, basar la proyección de la celebración en el morbo supone promocionar un espectáculo turístico vacío de significado cultural. La centralidad que adquiere la procesión en las narrativas visuales provoca, en muchos casos, el distanciamiento del conjunto. En este sentido se corre el riesgo de que no se entienda desde una práctica religiosa dramática, sino como una puesta en escena con la que deleitarse. Por eso, cuando los visitantes interfieren en la celebración, atentan contra el significado básico de la misma. Los devotos son parte de la comunidad presente; sin embargo, al cosificarlos y observarlos como un espectáculo público (no como una performance ritual), pierden la referencia de la comunidad, para volverse individuos anónimos, vacíos de significado y de valoración comunitaria: se convierten en objeto de exposición; en actores de una obra de ficción.

Esta deshumanización se manifiesta, además, en la práctica generalizada de persecución fotográfica de los rostros dentro de los ataúdes que rompe el clímax ritual y la intimidad personal. En muchos casos, la búsqueda de la imagen concreta, individual y personalizada es simplemente para mostrar en las redes sociales y que atestigüe «yo estuve allí»», como fórmula para diferenciarse de la tiranía de lo igual.

En general, desde todos los medios e instituciones, es necesario, reflexionar sobre nuestro papel de espectadores y sobre las interferencias de nuestras acciones, 
ya sean voluntarias o involuntarias, sobre las distintas celebraciones; fomentando un turismo consciente e informado. Como sociedad y como potenciales turistas que somos en cualquier ámbito y espacio, debemos poner en valor nuestra responsabilidad con el lugar que visitamos y con las celebraciones que se realizan, respetando no solo los bienes y elementos patrimoniales, sino también a los actores sociales que forman parte de los rituales. Entendiendo la parte íntima de estas prácticas, pese a darse en entornos comunitarios, masivos y públicos.

Es esencial tomar conciencia del papel de cada participante y crear elementos que permitan disfrutar de la romería, sea cual sea el papel de cada actor social. Si los devotos sucumben a la presión del acoso fotográfico o a la constante pérdida de identidad ritual, para convertirse en parte de una representación turística, no solo se perderá la principal motivación de la celebración (la mediación de la santa en procesos de saludenfermedad) sino que la experiencia individual de sacrificio-recompensa que motiva esta práctica, podría ser abandonada; o sustituida, como ya ha sucedido en otros casos, por un espectáculo orquestado y planificado, con actores profesionales, reproduciendo una banalización de los sentimientos y sufrimientos que se representan.

Pero, sobre todo, es necesario tratar de reducir la carga de exotización y morbo en la promoción de ciertas expresiones culturales, como la de Ribarteme. Y aquí los medios de comunicación tienen un papel esencial que no pueden eludir. Está claro que la curiosidad va a acompañar constantemente esta celebración, que manipularla para lograr un mayor alcance es fácil pero, también, que este tipo de prácticas conducen a tensiones que pueden dar lugar a una reconfiguración de la celebración y de su significado. Independientemente del espacio de participación, debemos revisar la imagen proyectada para hallar caminos comunes, con itinerarios que se interconecten, pero que no se superpongan.

\section{BiBLIOGRAFÍA}

Anónimo: «Five best... weird festivals», The Guardian, 28 de Junio de 2008. URL: $<$ https://www.theguardian.com/travel/2008/jun/28/fivebest.festivals $>$

AnÓNImo: «Vídeo: Así fue la romería de los "resucitados” en Santa Marta de Ribarteme, en As Neves», El Faro de Vigo, 29 de Julio de 2018. Facebook.

Augé, Marc (2018): «El viaje como ilusión y como promesa», AIBR, Revista de Antropología Iberoamericana, 13 (01), pp. 11-21. DOI:10.11156/aibr.130102.

Banks, Marcus (2010): Los datos visuales en investigación cualitativa. Colección: Investigación Cualitativa. Madrid: Morata.

Beaulieu, Anne (2004): «Meditating Ethnography: objectivity and the making of ethnographies of the internet», Social Epistemology, 18 (2-3), pp. 139-164.

URL: $\quad<$ http://www.virtualknowledgestudio.nl/staff/anne-beaulieu/documents/ mediating-ethnography.pdf $>$.

Bentham, Jeremy (1979) [1770]: El panóptico. Madrid: Las ediciones de La Piqueta.

CHAPLIN, Elisabeth (1994): Sociology and Visual Representation. Londres: Routledge.

DOMÉNECH, Miquel y TIRADO, Francisco Javier (2004): «El papel de las nuevas tecnologías en la producción de conocimiento», en Las nuevas tecnologías en la enseñanza. Temas para el usuario, Antonio Bautista García-Vera (coord.), Madrid, Universidad Internacional de Andalucía, Akal, pp. 31-60. 
Domínguez Figaredo, Daniel (2007): «Sobre la intención de la etnografía virtual», Revista Electrónica de la Educación: Educación y Cultura en la Sociedad de la Información. Vol. 8, 1. Universidad de Salamanca. URL: <http://www.usal. es/ -teoriaeducacion/rev_numero_08_01/n8_01_dominguez_figaredo.pdf $>$

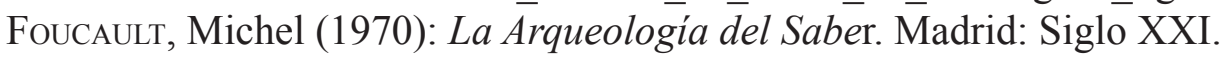

FouCAult, Michel (1979): Vigilar y castigar. Madrid: Siglo XXI.

Foucault, Michel (1980): Power/Knowledge: Selectec Interviews and Other Writings 1972-1977. New York: Pantheon.

Gárate Castro, Luis (1998): Los sitios de la identidad. El Bajo Miño desde la perspectiva de la antropología simbólica. A Coruña: Servicio de Publicaciones de la Universidade da Coruña (UDC).

GeERTz, Clifford (1993): La interpretación de las culturas. Barcelona: Gedisa.

Gell, Alfred (1998): Art and Agency: An Anthropological Theory. Oxford: Clarendon.

Han, Byung-Chul (2017): La expulsión de lo distinto. Barcelona: Herder.

Hine, Christine (2004): Etnografia Virtual. Colección Nuevas Tecnologías y Sociedad. Barcelona: UOC.

Latour, Bruno (2001): La esperanza de Pandora. Barcelona. Gedisa.

Lisón Tolosana, Carmelo (1990): La España mental: el problema del mal. Demonios y exorcismos en Galicia. Madrid: Akal.

Lisón Tolosana, Carmelo (2012): Teoría etnográfica de Galicia. Madrid: Akal.

Minder, Raphael: «El pueblo donde los vivos se meten en ataúdes para agradecer que no se han muerto», The New York Times, 5 de Agosto de 2017. URL: <https:// www.nytimes.com/es/2017/08/05/espanol/el-pueblo-donde-los-vivos-se-metenen-ataudes-para-agradecer-que-no-se-han-muerto.html $>$

MinDER, Raphael: «Un ritual donde los vivos pasan un día "muertos” como agradecimiento», Blog El Observatorio Cuyano, 4 de Agosto de 2017. Reproducción del original. URL: <http://elobservatoriocuyano.blogspot.com/>

MindER, Raphael: «Vivos se fingem de mortos em festa religiosa na Espanha», Bol Noticias, 4 de Agosto de 2017. Reproducción del original. URL: <https://noticias.bol.uol. com.br/ultimas-noticias/internacional/2017/08/04/vivos-fingem-de-mortos-emfesta-religiosa-na-espanha.htm>

Palleiro, Verónica: «Santa Marta, protagonista de National Geographic», El Faro de Vigo, 30 de Julio de 2013. URL: <https:/www.farodevigo.es/sociedad-cultura/ 2013/07/30/santa-marta-protagonista-national-geographic/853135.html>

Pena Castro, María Jesús (2004): «El negocio de la historia en la Feria Medieval de Noia», Sociológica. Revista de pensamiento social, 5, pp. 81-100.

Portal Web del Santuario de Santa Marta de Ribarteme. URL: <http://santamartaderibarteme. org $>$

Rodríguez-Becerra, Salvador (1989): «La Romería del Rocío, Fiesta de Andalucía», El Folclore Andaluz. Revista de cultura tradicional, 3, pp. 147-152.

Rodríguez BeCERrA, Salvador (1999): «La comunicación con lo sobrenatural en el Santuario de la Virgen de la Cabeza (Andújar), en Religión y Cultura, Salvador Rodríguez Becerra (coord.), Volumen 2, Sevilla, Junta de Andalucía, Consejería de Cultura y Fundación Machado, pp. 129-137.

Rodríguez Becerra, Salvador (2009): Las Romerías. Ritos y símbolos. Salamanca: Centro de Cultura Tradicional.

TÉBAr, Roma: «Mejoras en el entorno de la iglesia de Santa Marta», Atlántico Diario, 28 de Julio de 2018. 
TuRner, Víctor (1988): El proceso ritual. Madrid: Taurus.

Velasco, Honorio (1982): Tiempo de fiesta. Colección Alatar. Madrid: Editorial Tres Catorce Diecisiete.

Fecha de recepción: 24 de febrero de 2020

Fecha de aceptación: 27 de junio de 2020

$$
9
$$

